\title{
The EU Administrative Institutions, Their Law and Legal Scholarship
}

Joana Mendes ${ }^{1}$

\begin{abstract}
The chapter approaches the EU administrative institutions as catalysts of the development of administrative law of the European Union. As a chapter of the Oxford Handbook on Comparative Administrative Law, it explains the main traits of those institutions, how legal scholarship has portrayed them and how it has addressed the core aspects of their legal regimes. Furthermore, it traces the emergence and current state of EU administrative law, characterising the different roles comparative administrative law has had at different stages. It highlights the initial dissonance between the specificities of the EU administrative institutions and the statematrix of general principles that were developed on the basis of functional comparison; the role of legal scholarship in shaping EU administrative law, in its efforts to give effect to an "utopia" (Chiti, 2007) of an integrated administration constitutionally framed by general principles and fundamental rights; the limits of resorting to comparative administrative law in the context of EU integration and, briefly, the crossroads at which EU administrative law currently stands.
\end{abstract}

The dominance of administrative institutions in regional and global governance is a truism in many important areas of social and economic life. Food quality, pharmaceuticals, product safety, environment, technology and communications are only a few examples. In all these areas, regulation relies on specialised knowledge, discourses and legal acts developed within and adopted by international, regional and national administrative institutions, which, thereby, and by force of the powers allocated to them, have become central to modern government. At the same time, the proliferation of administrative institutions beyond the state challenged the role and functions of their national counter-parts. They have emerged largely detached from constitutionally framed or stable procedural and substantive rules that, within a state-setting, had provided safer ground for the protection of rights and the legitimacy of democratic processes (Sand, 1998, 274), and they evolved as those rules were being framed. As they progressively changed the governing conditions within the state, the challenges they have posed to democratic government and to rights' protection soon became those of national administrative institutions too (Sand, 1998, 276). From this perspective, the 'level' image, whereby supranational and transnational administrative institutions operate 'beyond the state' is as deceptive as it is descriptively appealing.

This chapter will focus on the administrative institutions of the EU. It is hoped that the Eurocentric-bias of the analysis can nevertheless be useful as a reference point for the study of

\footnotetext{
${ }^{1}$ I would like to acknowledge helpful suggestions by Peter Cane and Filipe Brito Bastos.
} 
administrative institutions that have developed outside the territorial boundaries of the state in other parts of the world, in the context of regional integration. The term "institutions" is understood here as meaning a social structure established for the performance of a specific function, in which power is subordinated to that end and in which such subordination justifies the structure's autonomy and, possibly, its legal personality (Hauriou, 1943, 25-27). Specific to administrative institutions are their legally assigned functions to pursue given public interests, typically associated with the concretization and management of public programmes, the implementation of legal norms, and the provision of public services. Beyond the state, such administrative functions are often materialized in the adoption of rules, in collaborative schemes of information-sharing, and in composite schemes of decision-making involving actors situated at different governance 'levels'. Supranational and transnational administrative institutions carry out those functions with different degrees of autonomy from national administrations with the purposes of pursuing integration, either within the scope of legally assigned functions or informally, at a distance from, but at the same time involving, national administrations. The term 'supranational' presupposes formal organic autonomy from Member States and the ability of administrative institutions to adopt legal acts that can bind the Member States unilaterally. Not all EU administrative institutions fulfil this criterion. The term 'transnational' is used here as a residual category to refer to those institutions that act across international borders with (relative) functional autonomy vis-à-vis Member States by virtue of their attributed tasks and informal action. The chapter approaches such administrative institutions as catalysts of the development of administrative law of the European Union. The first part explains their main features, how legal scholarship has portrayed them and how it has addressed the core aspects of their legal regimes (Sections 1 and 2). The second part shifts the focus to the emergence and current state of EU administrative law and of the role of comparative administrative law therein (Sections 3 and 4). It highlights the initial dissonance between the specificities of the EU administrative institutions and the state-matrix of general principles that were developed on the basis of functional comparison; the role of legal scholarship in shaping EU administrative law, in its efforts to give effect to an "utopia" (Chiti, 2007) of an integrated administration constitutionally framed by general principles and fundamental rights; as well as the functions that comparative administrative law performed in different stages of EU administrative law, its current limits and, briefly, the current challenges of EU administrative law.

\section{Administrative institutions within a supranational organization}


The role of administrative institutions in the process of European integration remained largely in the shade until the mid 1980s, when the goal of completing the internal market placed the effectiveness of Community law and its implementation in the forefront of the political agenda and (perhaps less so) of academic debate (Cassese, 1987, Chiti, 2013). The difficulties in delimiting an administrative function distinct from other functions exercised by the EU institutions (but see Schwarze, 1992 [2006], 21-24), and in identifying the administrative traits of institutions that both resembled and were distinct from those of national administrations may partially explain this relative neglect. Nevertheless, they went hand in hand with the progressive development of structures and procedures designed to carry out the implementation of EU law that, since the outset, transcended the reach of national administrations. Early scholars who sought to isolate the building blocks of an EU administration identified two main features. First, the centrality of the Commission within an administrative system of blurred contours, made of institutions and procedures set up for the implementation of EU law. It is with regard to the Commission, and to its counter-part in the European and Coal and Steel Community, the High Authority, that the Court first elaborated the general principles that, being purportedly common to the traditions of the Member States, have a clear administrative imprint. ${ }^{2}$ It is also the Commission that provided both public administration and administrative law scholars with perhaps a 'safer' basis to demonstrate that their own categories and models could be a fruitful lens to analyse supranational institutions, given the Commission's bureaucratic organization and function (Cassese, 1987, 20; Cassese and Cananea, 1992). The second feature was the functional and legal intertwinement between the Commission and national administrations in various patterns. Since the outset, national administrations had the primary competence to implement EU law and to carry out any activity needed to ensure the fulfilment of EU law. Executive federalism provided the matrix. Administrative competences attributed to the Commission remained the exception, in line both with the model of European integration conceived by Jean Monnet and with the interests of the Member States that created the EEC (Frowein, 1986; Dubey, 2003; Schütze, 2010; Franchini, 2014). In the context of EU integration, national administrations acquired a European role, grafted onto the pre-existing institutions: they perform a European function, which they pursue following their own structures and procedures as defined in national administrative law (institutional and procedural autonomy: Mehdi, 2014). But the initially-conceived separation between a small and policy-confined EU-level administration, on the one hand, and national administrations subject to their respective legal orders, on the other, was soon belied by two parallel developments: the

\footnotetext{
${ }^{2}$ But, also, with regard to the internal administration of the institutions (Joined Cases 7/56 and 3-7/57, Algera and others v Common Assembly of the European Coal and Steel Community, EU:C:1957:7).
} 
progressive involvement of the Commission in the implementation of Community policies (Noël, 1963; Chiti and Franchini, 2003); and the growth of committees composed of Member States' administrations and Commission representatives that accompanied the expansion of the Commission's functions. "Intermingling bureaucracies" were - and remain - present in virtually every area of Community action, albeit within different structures, with different functions and significance, and involved at different stages of the policy process (Pag, 1987, 447, 455; Hofmann and Türk, 2007; Chiti, 2009; Trondal, 2010, 4-8). They evolved as the establishment of direct effect and supremacy of Community law laid out the basis of the normative integration that characterises EU law (Chiti, 2013, 56-67).

In such context, divisions between a national and a European level were significantly blurred. As an early commentator put it, “descriptions of the Community as 'above', 'alongside', or 'outside' the Member States are useless oversimplifications" (Pag, 1987, 446). The intertwinement between EU and national administrations was such that one of the first studies on the EU administration asked whether such an EU administration existed or whether the "Brussels bureaucracy [was] only a mechanism aimed at ensuring cooperation between national administrative bodies" (Cassese, 1987, 9). While the emphasis was (and remains) on cooperation, scholars also pointed out the tensions between the European and national components that equally permeate this complex system (Pag, 1987, 447, 478; Cassese, 1987, 13-18). Such entanglement between supranational, transnational and national elements led to the creation of novel types of administrative institutions, comitology committees and agencies being perhaps the most prominent. ${ }^{3}$ The complex web of relationships between national and EU institutions became the centre of EU administrative law scholarship, which identified the phenomena, sought to organize them in different typologies, discern the implications of the administrative relationships stemming from various forms of collaboration, define both empirical and normative solutions, and scrutinize the way the EU Courts have developed general principles to govern these institutions (SchmidtAssmann, 1996; Chiti and Franchini, 2003; Hofmann and Türk, 2006; Cananea, Franchini, Macchia, 2017). Where lawyers tried to identify categories in consonance with the few indications that the Treaty provided, while heeding the reality of "intermingling bureaucracies" (direct administration, indirect administration, composite administration), public administration scholars mapped a "European administrative space" (Olsen, 2003). For lawyers, this angle of analysis, despite its attractiveness, risks hiding one fundamental feature of the EU administration: judicial

\footnotetext{
${ }^{3}$ See, further, Section 2.
} 
review remains anchored in a strict separation between the EU and the national jurisdiction (Brito Bastos, 2018).

\section{The study of the EU administrative institutions}

EU administrative law scholarship clustered around the Commission, comitology committees, EU agencies and administrative networks. While building on and developing categories of administrative organization, from a dogmatic perspective, it has also focused on the way in which institutional practices have shaped the interaction between EU and national administrations, and between them and private actors, as well as the respective political and legal implications. These administrative institutions will be the focus of the summary references that follow, with the purpose of mapping the main organic pillars of the EU administrative system (understood as an "articulated whole of organisations, procedures and administrative practices", Chiti, 2013) and of how they have been analysed in legal studies. ${ }^{4}$

\subsection{The Commission}

On the basis of its Treaty-assigned functions, the Commission can be characterized as an administrative institution. Article $17 \mathrm{TEU}$ gives visibility to an EU administration otherwise blurred in a complex fabric of collaboration with national administrations, of which the Commission is often also the motor (Majone, 1994). Concretely, the centrality of the Commission in the EU administrative system depends much on the policy area in which the EU operates. Within the limited areas of direct administration - competition, state aids, civil service and budget implementation $^{5}$ - the Commission has ultimate responsibility for the administrative activity pursued to implement EU law, which is also judicially and administratively enforced at the EU level (Chiti, 2013, 50; Ziller, 2014, 241). In this role, particularly in the competition area, it interacts directly with legal persons. Nevertheless, the emphasis on such direct responsibility, at the core of the category direct administration, ought not overshadow the fact that even in areas such as competition and state aids, the Commission remains a "second grade institution" (Cassese, 1987, 10). It is able to rely largely on collaboration with other European or national administrative bodies

\footnotetext{
${ }^{4}$ Other EU institutions have received uneven attention in their capacity of administrative institutions: the Council, to which the Treaties assign important administrative functions (e.g. Articles 31, 75(2), 43(3), 126(6), 215, 291(2), all of the TFEU), has been the object of much academic debate regarding the adoption of terrorist sanctions against individuals and entities suspected of terrorist involvement and the respective procedures (e.g. Cananea, 2011); similarly, the administrative role of the European Central Bank as banking supervisor has received significant scholarly attention (e.g. Chiti and Recine, 2018). The European Ombudsman and the Court of Auditors are issue-specific control bodies that are equally part of the EU administrative system (Chiti and Greco, 2007; Craig, 2018; Auby and de la Rochère, 2014, Hofmann, Rowe, Türk, 2011).

${ }^{5}$ E.g. Articles 105, 106, 108 TFEU and 317, $1^{\text {st }}$ paragraph TFEU.
} 
in performing the administrative functions and, eventually, adopting the legal acts for which it is responsible (Chiti, 2013, 50; Craig, 2012, 5-6, 23-24, 27-28; Hofmann, Türk and Rowe, 2011, 259260). "Modernization" reforms in both competition and state aids, anchored on decentralization of enforcement tasks to national administrations, have enhanced this aspect of direct administration, leading to the creation of networks and placing information-sharing and electronic systems at the heart of these policy fields, with the aim of enabling the Commission to focus its resources on the large-scale infringements of EU law (Harlow and Rawlings, 2014, 205-210; Colombo, 2019). In addition, it is also noteworthy that the EU administrative system has evolved in such a way that, beyond the Commission, also the European Central Bank has acquired functions of direct administration in the field of banking supervision (Pizzolla, 2018). ${ }^{6}$

\subsection{The comitology committees}

Comitology committees - composed of representatives of Member States' administrations and chaired by a member of the Commission - are perhaps the most paradigmatic form of administrative collaboration between the EU institutions and national administrations, central for the provision of expertise and for the mutual accommodation of the positions of national administrations. They are adjunct bodies, legally detached from the Commission, that assist and condition the exercise of its implementation powers (now under Article 291 TFEU). ${ }^{7}$ Having originally been a response to political problems that the conferral of powers of the Council on the Commission posed to the EU institutional system (carefully crafted to balance these two institutions), they remain a core institution of the EU administrative system. Since the outset of EU integration, comitology committees have enabled national governments and administrations to monitor and influence the exercise of the Commission's implementing powers. While being a means of control over powers delegated to the Commission, comitology committees have also fostered the emergence of supranational solidarities that were seen as "the centre in which a European administrative 'style' may develop" (Cassese, 1987, 16; Bergström, 2005, 32). Control and collaboration occur via various types of procedures, which have changed throughout the process of integration, pushed by inter-institutional struggles. These have triggered important constitutional developments (e.g. Bergström, 2005; Hofmann, Türk and Rowe, 2011, 223-255;

\footnotetext{
${ }^{6}$ Also EU agencies that have final decision-making powers (see section 2.3.) fall prima facie under the category of direct administration (those agencies have the ultimate responsibility for the implementation of EU law, subject to judicial and administrative enforcement at the EU level). Constitutionally, however, they operate under a legal framework distinct from that of the EU institutions (Chamon, 2018, Chapter IV).

${ }^{7}$ See (Article 3(2) Regulation 182/2011 and Articles 5(3), 9 and 12 of for Standard Rules of Procedure Committees (OJ C 206, 12.07.2011, p. 11-13).
} 
Craig, 2018, 113-121, 126-137) and ultimately culminated in the current distinction between delegated and implementing acts enshrined by the Lisbon Treaty (Articles 290 and 291 TFEU). ${ }^{8}$

Comitology gave rise to a wealth of legal literature, reaching well-beyond the confines of EU administrative law. Many highlighted the importance of comitology in shaping EU law and policy and its impacts on EU constitutionalism and democracy (e.g. Pedler and Schaefer, 1996; Wessels, 1998; Joerges and Vos, 1999; Dehousse, 2003; Christiansen and Larsson, 2007; Dehousse, Fernández Pasarín and Plaza, 2014). Much debate arose from the hypothesis of deliberative supranationalism, according to which committees were the setting for deliberative political processes undertaken in the search for a Community decision (Joerges and Neyer, 1997; Joerges and Vos, 1999; Joerges and Dehousee, 2002; Joerges, 2006). Organically, comitology was analysed essentially as a component of the EU's composite or integrated administration (Chiti, 2013, 69; Hofmann, Rowe, Türk, 2011, 264-281). Most of the theoretical disputes appear to have subsided today. The current debates in EU legal scholarship on comitology have shifted to the delimitation between delegated and implementing acts, and their respective institutional implications (Articles 290 and 291 TFEU). While, as a matter of legal design, comitology committees are only operational in the adoption of implementing acts, committees composed of Member State representatives remain active in the realm of delegated acts (e.g. Schütze, 2011; Bergstörm and Ritleng, 2016; Tauschinsky and Weiß, 2018), it being unclear the extent to which such Article 290 expert committees are the same as Article 291 comitology committees, albeit acting under different procedures (Craig, 2018, 129-131).

\subsection{EU agencies}

EU agencies are another institutionalised form of collaboration between the Member States' administrations. They have legal personality and are established by secondary legislation to carry out EU administrative functions. The term "European agencies" encompasses various types of bodies, a reality clearly expressed in a report by the European Ombudsman ("there are no simple answers to the questions 'what is an EU agency?' and 'what do EU agencies do?"'). ' The so-called decentralised agencies have been at the core of the literature on agencies, but they are far from being an homogenous group. ${ }^{10}$ Their organic traits and specific functions - they may have

\footnotetext{
8 The current comitology procedures are defined in Regulation 182/2011 laying down the rules and general principles concerning mechanisms for control by Member States of the Commission's exercise of implementing powers (OJ L 55, 28.2.2011).

Report on visits to Agencies, December 2014, p. 1 (available at http://www.ombudsman.europa.eu/activities/visitreport.faces/en/59248/html.bookmark\#_ftn2).

10 They are, nevertheless, different from executive agencies, which perform their tasks under the "control and responsibility" of the Commission, for a limited period of time (subject to extensions and renewals) to manage Union programmes, in accordance with the common statute defined in Regulation No 58/2003, of 19 December 2002 laying
} 
instrumental powers in support of the EU institutions (mainly, of the Commission and the Council), final decision-making powers in given instances, or operational powers - depend largely on the specific needs of regulation of the fields in which they operate. They have their own governing bodies and powers to manage their budget (generally, a financial contribution from the general EU budget), which give agencies administrative and financial autonomy vis-à-vis the Commission or the Council services. Yet, both the Commission and the Member States represented on the agencies' governing boards - retain significant influence over their action, thereby challenging their independence (Chiti, 2009, 1399-1400). The degree of influence depends on the respective agencies' founding regulations and on how they relate concretely to national regulatory authorities (Chiti, 2009, 1429-30). Their mixed composition confirms the "in-between" nature of agencies: they are EU administrative institutions created by a Union legislative act to fulfil EU functions, but Member States are present and influential in their governance structures (Everson, Monda, Vos, 2014). Still very few in the 1970s, EU agencies have proliferated in a series of "waves" and operate today in a wide variety of fields of EU law (e.g. Chamon, 2016, 5-15).

Besides their specific features that distinguish them from their national counterparts, their governance structures and independence, predominant themes in EU legal scholarship on EU agencies have been the limits of their powers, their anchorage in the Treaty (the legal basis for their adoption), their accountability (Busuoic, 2013), and their impact on the EU's politicaladministrative order (e.g. Chamon, 2016; Simoncini, 2018). The latter two are concerns which legal scholars share with their political science and public administration colleagues (Egeberg and Trondal, 2017). The fact that EU agencies have mostly instrumental powers, and have final decision-making powers only in individual decision-making is largely attributed to the long-lasting influence of two early judgments. Meroni and Romano limited significantly the types of powers that may be conferred on or delegated to EU agencies (albeit referring, respectively, to delegation to private law bodies in the context of the European Coal and Steel Community, and to an Administrative Commission with decision-making powers that were not subject to judicial review). ${ }^{11}$ Meroni prevented the attribution of wide discretionary powers to bodies set up by the institutions, Romano excluded that these could be given the power to adopt binding acts of general application (although the meaning and implications of this judgment, in particular its references to “acts having a force of law” was contested: see Chamon, 2011). The 2014 Short-selling judgment pertaining to the powers of one of the EU financial agencies confirmed that Romano's limitation

\footnotetext{
down the statute for executive agencies to be entrusted with certain tasks in the management of Community programmes (OJ L 11/1, 16.1.2003).

${ }_{11}$ Case 9/56, Meroni v High Authority, EU:C:1958:7; Case 98/80, Romano v Institut national d'assurance maladie-invalidité, EU:C:1981:104.
} 
applied to bodies not subject to judicial review, placed it in the shade of Meroni and loosened the strictures of Meroni. In this judgment, the Court admitted that EU agencies may be given discretionary powers as long as these are clearly circumscribed and subject to judicial review. ${ }^{12}$ This judgment has been hotly debated (e.g. Chamon, 2016; Simoncini, 2018), having potentially marked the transition to a new constitutional regime of the EU agencies (Saurer, 2017). More recently, two other themes have gradually caught the attention of EU legal scholars: the external dimension aspect of the EU agencies' powers (Groenleer and S. Gabbi, 2013; Chamon and Demedts, 2017; Coman-Kund, 2017; Meissner, 2017) and, from a more classical administrative law perspective, the channels of administrative review envisaged in the EU agencies with decision-making powers (e.g. Marchetti, 2017; Chirulli and de Lucia, 2018).

\subsection{National administrations and networks}

In an administrative system in which, despite the proliferation of EU bodies, national administrations retain the bulk of administrative functions, networks are functionally central to many EU legal regimes. Being less institutionalized than comitology committees and agencies, the horizontal processes associated with transnational cooperation occur, perhaps more distinctively, within networks. Networks can operate, as it were in a vertical relationship, under the aegis of the Commission, and also within EU agencies, some of which have evolved from a prior network structure, e.g. in the field of telecommunications and financial services. Apart from such "agencification of networks", complex relationships may intercede between networks and agencies operating in the same policy field (Levi-Faur, 2011). Networks are perhaps best described as intermediaries between the Commission or EU agencies, on the one hand, and Member States' administrations, on the other, acting through voluntary collaboration, deprived of formal decisionmaking power but having a role separate from those of both the Commission (or an EU agency) and national administrations (Blauberger and Rittberger, 2015).

Networks are often information-gathering structures, which support decision-making and enforcement, and sites for cooperative action. They may be mandated by EU legislation or emerge informally as a result of regulatory needs in a specific field. Depending on the field in which they operate, they may involve national independent authorities (regulators), departments of national administrations (e.g. in the framework of mutual assistance), as well as private entities, local, regional, national and European authorities. Networks of regulators have been the object of most academic attention, a focus that has left in the shade similar collaboration structures that exist in

${ }^{12}$ Case C-270/12, UK v Parliament and Council, EU:C:2014:18. 
fields where independent regulatory authorities do not operate (Mastenbroek and Sindbjerg Martisen, 2018, 426, referring to political science literature). Databases often operate as elements connecting the members of a network. An example is SOLVIT, a dispute resolution mechanism that relies on cooperation between national administrations and the European Commission, established to improve enforcement of internal market regulation via information-sharing and the promotion of common practices (Lottini, 2016).

\section{Normative solutions: comparative law and EU administrative law}

\subsection{Emergence: the founding role of comparison}

The creation and evolution of EU administrative institutions gave rise to new centers and forms of exercise of public power, as well as to new legal administrative relationships. Being legally and politically enmeshed in domestic administrative institutions, national administrative law appeared a natural resource and 'a rich repository' upon which an emerging and constantly evolving legal system could be built. The Court of Justice developed EU law by resorting to functional comparison, relying on the "general principles common to the legal systems of the Member States". ${ }^{13}$ The first administrative law scholars followed suit. Comparison was a means of overcoming the "general thinness of [then] existing European administrative law" (Schwarze, 1992 (2006), 54, 71-75), largely by resorting to the categories and principles of national administrative law. Both in case law practice and in doctrinal analyses, the normative perspective was one of progressive integration, at the service of building Europe. The work of Jean Rivero had a strong influence in this regard (Schwarze, 1992 (2006), 93-94, 1441). In a study published in 1978, Rivero stressed the commonalities between the administrative legal orders of the then nine Member States, whether from the perspective of "the problems that they seek to address, [of] the ideology from which they derive their solutions, or [of] the concrete results they achieve" (Rivero, 1978, 390). It was the stress put in these commonalities - "same societies, same ideology, same concrete effects" (Rivero, 1978, 391) - that underlay resort to comparative administrative law in subsequent works (Schwarze, 1992 (2006)). Rivero also pointed out important differences (such as the scope of acts subject to the jurisdiction of administrative courts, and the different type of legal actions available vis-à-vis administrative action), but these did not deny the fact that the legal orders of the then nine Member States stemmed from the same scientific and technical basis: the limits placed by law on the exercise of public authority (Rivero, 1978, 397-404). Differences in the solutions

\footnotetext{
${ }^{13}$ E.g. Joined Cases 7/56 and 3/57 to 7/57, Algera and Others v Common Assembly, EU:C:1957:7; Joined Cases C-46/93
} and C-48/93, Brasserie du Pêcheur and Factortame and Others, EU:C:1996:79, para 27. 
given to legal problems could progressively be overcome, as the Court of Justice identified common denominators and defined new concepts that would imbue and unify national administrative laws (Rivero, 1978, 405).

The Court has indeed played a fundamental role in this regard, in its search for the legal solutions that both best suit the objectives of EU integration, even if shared only by a relatively small number of Member States, and that can be considered acceptable for the national legal orders (Lenaerts and Gutman, 2015, 152 and 153). The view that national norms are "internal' to European Union law", by force of normative integration, or, at least, the fact that they "inform and nourish the interpretation and formulation of EU law" (Lenaerts and Gutman, 2015, 141) facilitated comparative work. In this way, the administrative institutions of the Communities and, later on, of the Union, despite their specificities, became governed by a law created in the image of national administrative law, while involving some degree of legal and political compromise (hitherto difficult to assess, given the secrecy of judicial deliberations and the absence of dissenting opinions). That law was based on the same principles known in national legal systems, as stated by the Court and framed by EU-specific, equally judge-made, legal principles (chiefly among them, direct effect and primacy). However, it resorted to different techniques of translating them into legal effects, in a dynamic of mutual interaction, cross-fertilization and transformation. Legal scholars were ready to acknowledge the specific nature of the EU legal order as well as the constitutional and structural differences between state administrative institutions, on the one hand, and EU administrative institutions, on the other. Yet, there has been little critical distance from the lead the Court of Justice has taken to vertical, functional comparison, and little scientific reflection on what this approach meant for how political power was, thereby, organized and structured in the EU. On the contrary: a product of its time, administrative legal doctrine concerned with European integration was engaged in convincing a skeptical majority that administrative law had trespassed the boundaries of the state (Sandulli, 2015, 289), and it both endorsed and reinforced the way EU administrative law was progressively emerging.

Jürgen Schwarze's monograph is, undoubtedly, a landmark in this respect. His was the first attempt to systemize EU administrative law, making visible prior sparse research on administrative law aspects of Community law (Schwarze, 1988, later translated into French and English; on precedent work, see Chiti, 2013, 53-56, 65-67 and Sandulli, 2015, 287-288). ${ }^{14}$ Schwarze focused on the judge-made principles both to assert the existence of a Community administrative law and to establish the doctrinal content of the case law by resorting to comparison, but reserved only a minor role to administrative institutions. He identified the different fields of direct and indirect

14 This analysis draws on the English translation (Schwarze, 1992 (2006)). 
implementation of Community law with the aim of providing a "basic review of the state of the art" (Schwarze, 1992 (2006), 39). In his view, the thinness and sketchy character of the thenexisting written rules that governed the activity of the supranational administrative institutions, from a general administrative law perspective (das allgemeine Verwaltungsrecht), justified a focus on general principles as an anchor of the development of EU administrative law. His approach was distinctively comparative. It covered the legal orders of the then twelve Member States with the aim of determining whether a common administrative law had already developed in the then Communities (Schwarze, 1992 (2006), 95, 1440). Conversely, he analyzed the EU legal order through selected legal regimes in which the Community administrative institutions were engaged to show that EU law reflected general principles of administrative law. The detailed analysis of supranational administrative institutions was sacrificed in a magnum opus that aimed at laying the ground for a new field of law and mapping the mutual influences between national legal orders, on the one hand, and the Community legal order, on the other (Schwarze, 1992 (2006), 1434). While some of the administrative institutions that would later emerge out of schemes of collaboration (namely, agencies) were far from being dominant at the time in which the book was written, it is nevertheless striking that Schwarze downplayed administrative collaboration as a distinct characteristic of EU law (also in the second edition: Schwarze, 2006, cxii-cviii; clxix-clxxxi; ccxxiii). This observation does not detract from the major importance of his work in the field. Also because it was translated, he became the "indisputable pioneer" of EU administrative law (e.g. Auby et Rochère, 2007, 3; Harlow, 2011, 445). His work illustrates well the interplay between legal scholars and the Court of Justice in setting down the "building blocks" of the administrative law of the then Community (on the role of the Court, see Chiti, 1991; Harlow, 2011, 444-450).

\subsection{Consolidation: implicit meta-use of comparison}

Others followed suit, albeit adopting different approaches to the study of the EU's administrative law and administrative institutions. The institutions created to carry out the EU administrative functions (almost absent in Schwarze's work) gradually acquired center-stage in academic analysis, as administrative scholars sought to establish the technical foundations of EU administrative law beyond its general principles. They delimited the concepts and principles and characterized the techniques of a new field of law, in an effort of synthesis, solidification and normative development. As a result, a new academic discipline progressively developed around the legal constructions and mechanisms "skillfully and meticulously designed" to implement EU law, evolving as a "patchwork... of solutions incrementally discovered" (Auby and de la Rochère, 2007, $6,19)$. Such patchwork easily escaped the systematization known in continental systems of 
administrative law. At the same time, the law that was emerging both impacted thereon and had features that administrative lawyers recognized as similar to national legal orders. Both factors prompted legal doctrine to seek the scientific systematization that could both stabilize existing law and ground future developments (Chiti, 1999). For this purpose, legal scholars resorted to the vocabulary and concepts of national legal doctrine, while, at the same time, seeking to adjust the normative solutions resulting from this exercise to a rapidly evolving system. Comparison was thereby relegated to an implicit meta-use, shaping the different perspectives on how EU administrative law was best systematized, explained and developed. How such scholarly effort developed will be mapped here briefly by reference to a selection of the main handbooks and treatises (leaving in the shade a wealth of rich literature that both preceded them and developed in parallel). To the extent that such volumes both attempt to analyse the law as it stands and develop new perspectives on the study of a discipline, they arguably provide a good general account of the evolution of the law that emerged to govern the EU administrative institutions. ${ }^{15}$

Mario Chiti and Guido Greco edited three comprehensive volumes in 1997 on general and special administrative law (preceded by Airoldi, 1990). Various contributors identified in EU law some of the main doctrinal categories that hitherto had anchored national administrative law (administrative procedure, administrative organization, techniques of judicial review, liability); the book, nevertheless, included chapters that could have also featured in a standard handbook on EU institutional law. In addition to the system of administrative law that applied to the thenCommunity, Chiti and Greco were concerned with the influence of this body of law in national administrative law. A second edition a decade later reflected already a different stage of development of EU administrative law, characterized by deeper integration between EU and national legal systems and a different degree of constitutional maturity, given the administrative law implications of the Charter of Fundamental Rights (namely, the right to good administration) and the ramifications of general principles of law for the organization and activity of, and controls over, the EU administration. Such developments did not hide the difficulties entailed in a dogmatic reconstruction of a system of principles and concepts suitable for the "new administrative law"; the editors noted, in fact, that the development of EU law tends escape systematic efforts (Chiti and Greco, 2007, xii-xiii). These difficulties notwithstanding, Chiti noted that what had for a long time been considered "the utopia of the lawyers of integration" had become a reality: an integrated administration, constitutionally framed by general principles and fundamental rights, had emerged (Chiti, 2007, 415-7).

\footnotetext{
${ }^{15}$ In addition to the references that follow, see also Birkenshaw (2014), Parejo Alfonso (2000); Von Danwitz (2008), Duarte (2008) Harlow and Rawlings (2014), Fuentetaja Pastor (2016). For a more detailed analysis and further sources on Italian scholarship, see Chiti (2013, 75-78) and, also on English and German scholarship, Sandulli $(2015,290)$.
} 
In the same decade, Paul Craig's volume dedicated to EU administrative law set the firm foundations for an administrative law analyses of the EU in the English-speaking world. Drawing on administrative reforms that followed the fall of the Santer Commission in 1999, Craig identified centralized and shared management as modes through which Community policy is delivered (highlighting the role of executive agencies in assisting the Commission to implement Community programmes), analysed the various interactions between $\mathrm{EU}$ institutions and national administrations established via comitology and agencies, as well as the open method of coordination. Craig thus mapped the EU administrative institutions to which the principles of judicial review developed by the EU Courts (and by the European Ombudsman) apply (Craig, 2006). ${ }^{16}$ Jean-Bernard Auby and Jacqueline Dutheil de la Rochère, in turn, delimited the legal corpus of EU administrative law by reference not only to the administrative law of the European Union (as applied to both EU bodies and national administrations implementing EU law), but also to its legal effects in national legal systems, the directions in which EU law was pulling national administrative law, and, in turn, how national administrative laws accommodated that influence (Auby and de la Rochère 2007). ${ }^{17}$ The part on administrative law of the EU is dedicated to the analysis of the Council and of the Commission (the EU institutions conventionally associated with the EU executive), administrative organization, forms of administrative action, administrative procedure and principles of administrative law. In this book, these are the issues that delimit the object of blurred contours of EU administrative law.

These major works solidified the scientific grounds of EU administrative law and the study of the administrative institutions of the EU at a time both of change and of impasse. The fall of the Santer Commission brought administrative reform to the forefront of the political agenda and ultimately led to a new public management ethos visible, for instance, in the 2001 White Paper on Governance (Craig, 2018, 36-55). The view expressed there was that a public-service-oriented EU administration ought to be anchored in openness, participation, accountability, effectiveness, and coherence - values that pointed a new direction for EU administrative law and its study. It spurred the development of EU executive and regulatory agencies and announced a reform of the existing comitology committees (White Paper on Governance, 2001, 23-4, 31). The Charter of Fundamental Rights, proclaimed in 2000, gave potentially a subjective imprint to EU administrative law, with fundamental rights framing important aspects of administrative law. Even if a decade would go by before the Charter acquired a legally binding character, Article 41 enshrined a fundamental right to good administration (codifying previous case law), Article 42 the

\footnotetext{
16 A second edition appeared in 2012 and a third in 2018.

${ }^{17}$ A second edition appeared in 2014 and a third is in preparation at the time of the writing.
} 
right to access documents, and Article 47 the right to an effective legal remedy. The Constitutional Treaty recognized the distinction between legislative and executive acts and set the constitutional foundations for the EU administration. Even though this Treaty was later rejected by the French and Dutch referenda, much of its content, including this distinction, eventually found its way to the Lisbon Treaty. If the EU administration had been hitherto somewhat "hidden" (Azoulai, 2009), it acquired a new prominence. As alluded to above, the handbooks on EU administrative law reflected this evolution. Hofmman, Türk and Rowe, writing in 2011, started their volume from the premise of a EU integrated administration with the aim of examining the extent to which it meets standards of democratic accountability, drawing out general administrative law from policysector specific developments (in tune with the approach that Schwarze had initiated), and mapping "the law governing the public administration of the EU ... its context, structure and institutions, competences and limits, relations and interaction, procedures, methods and controls" (Hofmann, Türk and Rowe, 2011, 20, 21).

\subsection{Maturity: shift in the role of comparison}

The function of EU administrative law became that of national administrative law, namely to ensure the efficiency of public action in the pursuance of public interests and protection of the rights and legally protected interests of private persons, albeit in a context of composite administrations inserted in webs of collaboration duties (Chiti, 2007, 416). This was the arrival point that EU administrative law scholarship had sought, reflecting the work of the EU Court (since, at least, Schwarze, 1992(2006)). The "same ideology" that Rivero had referred to - the liberal ideology - defined the rationale of EU administrative law both as a field of law shaped by the Court to regulate those acts of public authority, directed at constructing the internal market and the political union, that could be identified as fulfilling an administrative function, and as a field of scholarship. To a significant extent, scholars delimited the object of such endeavour by drawing on categories of national administrative law (administrative acts, contracts, liability, procedure), although the extent to which this was the case tended to reflect the national academic background of the author (the approaches of Craig and of Chiti and Greco, for instance, are quite different in this respect). Identifying such legal categories - encoding the material that EU law provided via implicit comparison - and drawing on administrative law principles enabled legal scholars to identify the harbingers of the administrative law of the EU, often elicited from the case law. The way in which the legal system that was thus being built transformed the administrative laws of the Members States was a discussion that (with exceptions) tended to remain largely a separate debate under the epithet of Europeanisation of administrative law (even where featuring 
in handbooks, as in Auby and Rochère, 2007 and 2014). Some highlighted that the competition and free market principles changed the "general interest" (intérêt general) ethos of national administrative law (Auby and Rochère, 2007, 15). Others argued that the main purpose of EU administrative law was the control of Member States (Shapiro, 1999; Harlow, 2011, 445). But, when analyzing general doctrinal categories and principles, most stressed that EU administrative law had developed to protect the rights and legally protected interests of individuals, to steer the reasonable exercise of administrative power, and to subject it to apposite controls.

Comparative administrative law (somewhat scattered and implicit) at the service of integration assisted in the massive work of unveiling, studying, and systematizing the variety and intensity of EU public action that went much beyond that envisaged in the Treaty, as well as the relevance of the administrative institutions that emerged in the context of EU integration. But comparative administrative law as a tool to build EU administrative law had an important weakness: it drew largely on legal categories and principles that EU law itself was helping to transform. EU law contributed to breaking the separation between public authority and the market, and between public authority and society, that had anchored the paradigm of administrative law within the state and that, simultaneously, provided the grounds to develop EU administrative law. The disruptive effect that EU law had on the binary relationships between public authority and private persons, that had anchored the conventional paradigm of administrative law, was duly noted (Cassese, 2003; Auby and Rochère, 2007) ${ }^{18}$ Nevertheless, the doctrinal concern to develop the scientific categories of EU administrative law, as it were. by 'transplanting' national concepts appears to have prevailed over an analysis of the normative effects that the EU legal regimes were generating in the context of European integration, with fundamental impacts on the allocation of public authority, both among public and private entities. The fact that, in the emergence and consolidation periods, administrative legal scholars working on EU law sought to establish the existence of a body of law whose existence most EU and administrative law scholars contested may partially account for this precedence. Those normative effects tended to be accepted as a consequence of the need to ensure the effectiveness of EU law and the inevitability of displacing the state in the process of integration, and as a reason to further perfect EU administrative law. The way EU law empowered private persons against the state administrations and relied on their collaboration to advance integration was largely taken as a natural consequence of integration. EU administrative law, with its liberal ethos, was both a means

18 The impact of EU law in national administrative law is the object of a large literature (e.g. contributions in Auby and Rochère, 2014). 
to address these transformations and to support them, by bringing them in line with the core tenets of the rule of law.

This very construct - perhaps more porous than their national counterparts to extra-legal concepts - quickly became permeated by the principles of transparency, efficiency, participation, accountability, leading to the development of procedural norms that could translate managerial demands into legal language and embody new promises of legitimacy of the exercise of public authority, under the heading of "good governance". Incorporated into legal regimes that were transposed to, or directly applicable in, the legal orders of the Member States, much under the impulse of the Commission's 2001 White Paper on Governance, these principles and norms also became part of the "droit commun européen" that Jean Rivero envisaged in 1978. They expressed the evolution that administrative law experienced as well at the national level (largely by effect of EU law): the progressive repudiation of the models and categories of legal discourse anchored on the premise of unilateral exercise of public authority on behalf of a better representation of the reality of diffuse authority spread through various networks. The creation of models and categories deemed more suitable to tackle the complexity of government is more in tune with the schemes of collaboration and intermingling bureaucracies that remain characteristic of the EU's administrative structures. But the ability of good governance principles to deliver on the promise of constraining the action of the EU institutions remains questionable (Harlow, 2016). In particular, there remains a weak integration between the constitutional concerns of framing and taming the exercise of public authority, on the one hand, and the institutional practice of collaboration and diffuseness of public authority in the EU administrative sphere, on the other. The fact that qualitatively new patterns of interaction between the public and the private spheres, generated by the process of integration, were framed by legal concepts and categories that traveled, somewhat anachronistically, from national administrative law to EU law, may be significant in this regard.

In this phase of maturity, the role of comparative law shifted. As the Lisbon Treaty appeared somewhat to overcome the thin constitutional foundations of EU administrative law, and as general principles of both jurisprudential and managerial origin provided underpinning for a still-unstable building, comparative law appeared now to gain primarily an analytical function, within a system already built, rather than a structural normative function, which it has, to some extent, already realized. If one may argue that the convergence process only reinforces the importance of comparative law, its role is to increase learning on how EU law issues are dealt with by different jurisdictions and understanding on how national laws may still influence or condition EU law (Caranta, 2009). From the perspective of convergence (prevailing hitherto), its role is no 
longer to set the foundations of the administrative rule of law in the EU. Even a refinement role in this regard may be limited by resorting to comparison. Indeed, one may question whether the reduction of the autonomy of national administrative laws as self-standing bodies of law (Chiti, 2016, 583) might have not eroded the ability of national administrative laws to function as a rich repository of normative solutions. One should bear in mind that comparison also inheres in administrative practice. National administrations themselves are confronted with the legal regimes with which they may compete in the context of supranational and transnational administrative institutions (Chiti, 2013, 74); and courts with different solutions provided by the counterparts of EU legal problems. In this vein, comparison contributes to further transforming or adjusting the system from within, less with a role of foundational construction than that of sharpening the legal techniques that have been built to bridge the gap between legal principles and legal problems (Rivero, 1978, 391). While the value of comparative law for purposes of critical evaluation continues to be acknowledged (e.g. Hofmann, Growe and Turk, 2011, 20-1), it may be unlikely that the normative yardstick for such critical evaluation can still be found within the contemporary administrative law systems and of their governance practices. In order to retain its critical function, comparison may need to be coupled with sources from other historical periods when administrative law emerged and underwent fundamental changes, with political theory that explores and unveils the ideological foundations that shape implicitly the prevailing approaches to concepts, principles, and techniques, or with sociological analyses that account for how norms circulate. Hitherto, such combined approaches have been absent in EU administrative law.

\section{EU administrative law: constitutionalisation, codification, crisis}

The Lisbon Treaty marked the beginning of a new phase, which most EU administrative law scholars embraced with enthusiasm (even if cautious with regard to the difficulties that some changes could pose, such as the distinction between delegated and implementing acts). If "it is in the Constitution that administrative law finds its headings" (Rivero, 1978), the quest by EU administrative law scholars for "legal clarity and normative precision" regarding the constitutional foundations of the EU administrative system appeared finally to have found solid ground in the Treaties and in the Charter of Fundamental Rights, beyond the case law of the Courts (Ruffert, 2017, 667, 670, 675). The main principles embodying an ideal of good administration were given the status of a binding fundamental right, building on previous case law; ${ }^{19}$ a new legal basis evidenced the need to ensure "an open, efficient and independent administration" (Nieto, 2012;

\footnotetext{
${ }^{19}$ See Article 41 of the Charter and the Explanations to the Charter.
} 
reference to Craig's article); ${ }^{20}$ administrative cooperation was finally acknowledged in the Treaty, as was the model of executive federalism. ${ }^{21}$

Such explicit constitutional foundations gave another impulse to EU administrative law scholarship, concerned with the liberal credentials of the EU regulatory state (Chiti, 2013, 83-85) and optimistic regarding the ability of procedural principles to realise the constitutional promises of the Lisbon Treaty (e.g. Curtin, Hofmann and Mendes, 2013). The discussions on a consolidation project in the form of a law on the administrative procedure, which had been for long regarded as premature (Schwarze, 1992(2006), 1453-55; Harlow, 1996), gained a new momentum (Galetta et al, 2016). The commitment to building a body of law consonant with liberal tenets focused academic efforts on the remaining gaps, to be filled by resorting to procedural principles and finetuning mechanisms of control. That was, in part, the purpose of the "Model Rules on EU Administrative Procedure", proposed by a group of scholars with a view to overcoming, to the extent possible and desirable, the fragmentation of procedural rules across policy sectors and to proposing common rules that could both consolidate the rights and duties of public bodies and individuals and serve as a reference to future legislation (among others, Galletta et al., 2016). Such work was both a sign of maturity of the body of law that had developed to rule the administrative institutions of the EU and the culmination of a decades-long scholarly effort that, building on judicial and legislative advances, has been premised on convergence, on the rule of law and on the effectiveness of the administrative processes required to give effect to EU law.

This work intersected with the political process. The European Parliament, having acknowledged the potential of a general law on the administrative procedure to provide clarity regarding the rights of private persons and to structure to an otherwise scattered body of legal rules, drafted a legislative proposal and requested the Commission to initiate the corresponding legislative procedure. ${ }^{22}$ But this unprecedented step - it was the first time that the European Parliament went as far as actually proposing a draft regulation, in addition to requesting the initiation of a legislative procedure - met institutional resistance. The Commission's refusal to proceed, more than a rejection of a specific proposal, is arguably an indication of a deeper trait of EU administrative law: notwithstanding its liberal foundations, it remains deeply functional, guided by the integrationist ethos that has shaped it since the beginning. The argument made here is not that the blockage of one legislative initiative can amount to denying the legal relevance of those constitutional foundations. These are anchored to a significant extent in a long-lasting process of

\footnotetext{
20 Article 298 TFEU.

21 Articles 197 and 291(1) TFEU, respectively.

22 European Parliament Resolution of 15 January 2013 with recommendations to the Commission on a Law of Administrative Procedure of the European Union (2012/2024(INL)), and Resolution of 9 June 2016 for an open, efficient and independent European Union administration (2016/2610(RSP)).
} 
judicial development of general principles that are, undoubtedly, of normative relevance also for future legal developments. But just as the normative indications one can draw from the Treaties and case law can express the state of development of EU administrative law, so too do institutional practices. At least at present, the relationships between the EU administration and private persons, and between the exercise of public authority and its control, do not appear capable of being shaped by general legal regimes detached from the functional purposes of integration. The lack of institutional support to the European Parliament's proposal show as much. It is noteworthy that this proposal is minimal in many respects: it carefully avoids contentious issues, codifies case law and legal norms scattered in legislation and aims at making visible the already existing links between EU administrative procedure and the constitutional principles that bind the EU administration. Overall, the liberal foundations of EU administrative law, as similar as they are to those of national administrative law, are perhaps not as developed as EU administrative law scholarship tends to assume (Chiti, 2016, 588), or at least, do not seem to be able to sustain a similar trajectory.

The entering into force of the Lisbon Treaty coincided with the various crises that beset the EU in tidal surges. These led to reforms that largely strengthened the role of EU administrative institutions, chiefly of EU agencies, in complex processes of coordination with national administrations (financial regulation, border control, asylum). The period that has elapsed since 2009 has shown clearly the malleability of the EU administrative institutions, adjusting to a new constitutional framework (the comitology committees) and to a new socio-economic context. Such context both facilitated the creation of yet a 'new generation' of agencies in the financial sector, accompanied by yet another complex web of "intermingling bureaucracies" (Pizzolla, 2018), and, simultaneously, shook the constitutional premises on which agencies had stood hitherto (Saurer, 2017). ${ }^{23}$ The shift of administrative functions, in highly sensitive policy areas, from Member States to the EU institutions and agencies, and the strengthening of administrative collaboration and operational capacity (e.g. Ritleng, 2017), combined with the unprecedented challenges to the liberal-democratic foundations of the EU polity, are significant developments which require critical reflection on the doctrinal categories and principles that have been developed hitherto to govern the supranational and transnational administrative institutions of the EU. The shifts in the allocation of public power, among both public and private actors, that the process of EU integration has facilitated - assisted by administrative law - may require a reassessment of how such doctrinal categories shape the relationships between society and the administrative institutions of the state and of the EU, and of the extent to which they serve to frame and categorize reality in a way that can be consonant with the liberal and social values that the EU legal

23 Shortselling judgment (n 12). 
system purports to uphold. At the same time, the tensions between functionalism and liberaldemocratic principles, and the interactions between managerial principles and general principles of administrative law, are consequential in shaping the EU administrative institutions and the law that governs them. Harlow's critique of the integration ethos of EU administrative law is perhaps more relevant today than a decade ago, as the drive towards convergence has weakened (Harlow, 2011, 463-4; Harlow and Rawlings, 2014, 9). But the pluralist alternative, where diversity co-exists with convergence, via EU soft law that allows adaptability to national, regional and local conditions, and is controlled via accountability networks is yet to fulfil its promises of strengthened legitimacy and inclusiveness. 


\section{References}

Airoldi, M. (1990). Lineamenti di Diritto Amministrativo Comunitario (Milano: Giuffrè)

Auby, J-B. and Dutheil de la Rochère, J. (2007[2014]), «Introduction » Auby and Dutheil de la Rochère (eds.), Traité de droit administratif européen, Brussels: Bruylant, $2^{\text {nd }}$ ed., 21-39 [2014]

Azoulai. L. (2009), "Pour un Droit de l'Exécution de l'Union Européenne » in J. Dutheil de la Rochère (ed.), L'Exécution du Droit de l'Union, entre Mécanismes Communautaires et Droits Nationaux, Brussels: Bruylant, 1-23

Bergström, CF. (2005), Comitology: delegation of powers in the European Union and the committee system, Oxford: Oxford University Press

Bergström CF. and Ritleng D. (2016) Rulemaking by the European Commission: the new system for delegation of powers, Oxford: Oxford University Press

Birkenshaw, P. (2014), "European public law: the achievement and the challenge (Aaphen an den Rhin: Kluwer, $2^{\text {nd }}$ ed.

Blauberger, M. and Rittberger, B. (2015), "Conceptualizing and Theorizing EU regulatory frameworks", Regulation \& Governance, Vol 9, pp. 367-76

Brito Bastos, F. (2018), "Derivative illegality in European composite administrative procedures", Common Market Law Review. Vol. 55, No. 1, p. 101-134

Busuioc, M. (2013), European Agencies: Law and Practices of Accountability, Oxford: Oxford University Press

Della Cananea, G. (2011), “Administrative Due Process In Liberal Democracies:A Post-9/11 World”, Italian Journal of Public Law (2), 195-223

Della Cananea, G. Franchini, C. Macchia, M. (2017) I principi dell'amministrazione europea, Torino, Giappichelli, 3rd ed.

Caranta, R. (2009), "Pleading for European Comparative Administrative Law", Review of European Administrative Law, Vol 2, no 2, 155-173

Cassese, S. (1987), The European Administration, Brussels: International Institute of Administrative Sciences

Cassese, S and della Cananea, G. (1992), "The Commission of the European Economci Community: the Administrative Ramifications of its Political Development (1957-1967)" in Jarbbuch für Europaïsche Verwaltungsgeschichte, No 4, 81-94

Cassese, S. (2003) "L'arena pubblica: nuovi paradigmi per lo Stato", Rivista trimestrale di diritto pubblico, N. 3 (2001), p. 601-650

Chamon, M. (2011), "EU Agencies Between Meroni and Romano or the Devil and the Dep

Blue Sea", Common Market Law Review, Vol. 48, pp. 1055-1075

Chamon, M. (2016), EU agencies: legal and political limits to the transformation of the EU administration Oxford: Oxford University Press

Chamon, M. and Demedts, V. (2017), Constitutional Limits to the EU Agencies' External Relations, TARN Working Paper Series 11/2017, Available at SSRN: https://ssrn.com/abstract $=3021733$ or http://dx.doi.org/10.2139/ssrn.3021733

Chirulli, P. and de Lucia, L. (2018), Rimedi amministrativi ed esecurione diretta del diritto europeo, Torino, Giappichelli,

Chiti, E. and Franchini, C. (2003), L'integrazione amministrativa europea, Bologna: Il Mullino

Chiti, E. (2009), 'The administrative implementation of European Union law: a taxonomy and its implications', Hofmann, H. \& Türk, A (Eds.), Legal Challenges in EU Administrative Law, Cheltenham: Edward Elgar, 9-34 
Chiti, E. (2009), "An important part of the EU's institutional machinery: features, problems and perspectives of European agencies", Common Market Law Review, Vol. 46 (2009), no. 5, p. $1395-1442$

Chiti, E. (2013), "La costruzione del sistema amministrativo europeo" in Battini, S. and Chiti, MP. (eds) Diritto amministrativo europeo (Milano: Giuffrè), p. 45-88

Chiti, E. (2016), "Is EU Administrative Law Failing in Some of Its Crucial Tasks?, European Law Journal, Vol. 22 No. 5, 576-596

E. Chiti and Recine, Fabio (2018), "The Single Supervisory Mechanism in action : institutional adjustment and the reinforcement of the ECB position", European Public Law. Vol. 24, N.1, p. $101-124$

Chiti, M.P. (1991), "I Signori del Diritto Comunitario: La Corte di Giustizia e lo Sviluppo del Diritto Amministrativo Europeo", Rivista Trimestrale di Diritto Pubblico 3, 796-831

Chiti, M P.(1999), Diritto Amministrativo Europeo (Milano: Giuffrè)

Chiti, M.P. (2007), "L'Organizzazione Amministrative Comunitaria", in Chiti. M.P. and Greco, G. (eds.) Tratatto di Diritto Amministrativo Europeo, Giuffrè, 415-466

Christiansen, T. and Larsson, T. (eds) (2007) The Role of Committees in the Policy-process of the EU: Legislation, Implementation and Deliberation, Cheltenham: Edward Elgar

Colombo. C. (2019), "State Aid Control in the Modernisation Era: Moving Towards a Differentiated Administrative Integration?”, European Law Journal, Vol. 25 No. 3, 292-316

Coman-Kund, F. (2017) The International Dimension of the EU Agencies Charting a LegalInstitutional 'Twilight Zone', TARN Working Paper Series 5/2017, Available at SSRN: https://ssrn.com/abstract=2951184 or http://dx.doi.org/10.2139/ssrn.2951184

Craig, P. P. (2006), EU Administrative Law (Oxford: Oxford University Press).

Craig, P. P. (2012), EU Administrative Law. 2nd ed. (Oxford: Oxford University Press).

Craig, P. P. (2018) EU Administrative Law. 3rd edition. (Oxford: Oxford University Press).

Curtin, D., Hofmann, H. Mendes J. (2013) "Constitutionalising EU executive rule-making procedures: a research agenda", European Law Journal, Vol. 19 (2013), issue 1, p. 1-21

Dehousse, R. (2003) 'Comitology: who watches the watchmen?', Journal of European Public Policy Vol. 10, No. 5 798-813

Dehousse, R., Fernández Pasarín, A. and Plaza J. (2014), "How consensual is comitology?”, Journal of European Public Policy, Vol. 21, No. 6, pp. 842-859

Duarte, M.L. (2008) Direito Administrativo da União Europeia (Coimbra: Coimbra Editora)

Dubey, B. (2003), “Administration indirecte et fédéralisme d'exécution en Europe" Cabiers de Droit Européen Vol. 39, No. 1-2, pp. 87-113

Egeberg, M., Schaefer, G. and Trondal, J. (2003) 'The many faces of EU committee governance', West European Politics 26(3): 19-40

Egeberg, M. and Trondal, J. (2017) "Researching European Union Agencies: What Have We Learnt (and Where Do We Go from Here)?”, Journal of Common Market Studies 55(4), 675690

Everson, M.; Monda, C., Vos, E. (eds) (2014) European agencies in between institutions and Member States, Aalphen an den Rhin: Kluwer

Fuentetaja Pastor, JA. (2016), Derecho administrativo europeo (Madrid: Civitas, 3rd ed.)

Franchini, C. (2014), "Les notions d'administration indirecte et de coadministration", in Auby and Rochère (eds.), Traité de droit administratif européen, Bruxelles: Bruylant, $2^{\text {nd }}$ ed., pp. 335355 
Frowein, JA. (1986), "Integration and the Federal Experience in Germany and Switzerland", in Cappelletti, Seccombe \& Weiler, (eds.) Integration through Law, Vol. 1, Book 1, pp. 573600, at pp. 586-587

Galetta, D.-U., Hofmann H., Mir Puigpelat, O., Ziller, J (2016) "Context and legal elements of a proposal for a Regulation on the administrative procedure of the European Union's institutions, bodies, offices and agencies", Rivista Italiana di Diritto Pubblico Communitario, 1, $313-360$

Groenleer, M. and Gabbi, S. (2013), "Regulatory Agencies of the European Union as International Actors Legal Framework, Development over Time and Strategic Motives in the Case of the European Food Safety Authority", European Journal of Risk Regulation, Vol. 13, No. 4, pp. 479-92

Harlow, C. (1996), "Codification of EC Administrative Procedures? Fitting the Foot to the Shoe or the Shoe to the Foot", European Law Journal Vol. 2 No 1, p. 3-25

Harlow, C. (2011), "Three Phases in the Evolution of EU Administrative Law" in Craig, P. and de Burca, G. (eds.) The Evolution of Eu Law (Oxford: Oxford University Press), 439-464

Harlow, C. and Rawlings, R. (2014) Process and procedure in EU Administration, Oxford: Hart

Harlow, C (2016), "Editorial: Transparency, Accountability and the Privileges of Power"

European Law Journal Vol. 23 No 3, 273-278

Hauriou, M. 1943. Précis Élémentaires de Droit Administratif, Paris: Sirey

Hofmann, H. and Türk, A. (2006), "Conclusions: Europe's Integrated Administration" in Hoffman and Türk, (eds) EU Administrative Governance (Edward Elgar)

Hofmann, H. \& Türk, A, (2007) 'The Development of Integrated Administration in the EU and its Consequences', European Law Journal, Vol 13, No. 2, 253-271

Hofmann H.,Rowe G., and Türk A. (2011) Administrative Law and Policy of the European Union

(Oxford: Oxford University Press)

Joerges, C. (2006) 'Deliberative political processes' revisited: what have we learnt about the legitimacy of supranational decision-making', Journal of Common Market Studies 44(4): 779_ 802

Joerges C., and Dehousse R. (eds.) (2002), Good Governance in Europe's Integrated Market

(Oxford:Oxford University Press)

Joerges, C. and Neyer, J. (1997) 'From intergovernmental bargaining to deliberative political processes: the constitutionalisation of comitology', European Law Journal 3(3): 273-99

Joerges, C and Vos, E. (1999), EU Committees. Social Regulation, Law and Politics (Oxford: Hart)

Leanerts, K and Gutman K (2015), "The Comparative Law Method and the Court of Justice of the European Union, Interlocking Legal Orders Revisited" in Mads Andenas and Duncan Fairgrieve (eds) Courts and Comparative Law (Oxford University Press), 141-17

Levi-Faur. D. (2011), "Regulatory networks and regulatory agencification: towards a Single

European Regulatory Space", Journal of European Public Policy Vol. 11, No 6, pp.

Lottini, M. (2016), "The SOLVIT Network and the Effective Enforcement of EU Law. What is New?" in Drake, S.; Smith, M. (eds) New Directions in the Effective Enforcement of EU Law and Policy (Cheltanham: Elgar) p. 130-151

Nieto, E. (2012) "Possible developments of Article 298 TFEU: towards an open, efficient and independent European administration" European Public Law, Vol.18(2), p.373-397

Majone, G. (1994), "The Rise of the Regulatory State in Europe”, West European Politics Vol. 17, No. 3 77-101 
Marchetti, B. (2017), Administrative Remedies in the European Union. The Emergence of a QuasiJudicial Administration (Torino, Giappichelli)

Mastenbroek, E. \& Sindbjerg Martinsen, D. (2018) "Filling the gap in the European administrative space: The role of administrative networks in EU implementation and enforcement" Journal of European Public Policy, Vol. 25 (3), 422-435.

Mehdi, R. (2014) "Le principe d'autonomie institutionnelle et procédurale et le droit administratif ", in Auby and Dutheil de la Rochère (eds.), Traité de droit administratif européen, Brussels: Bruylant, $2^{\text {nd }}$ ed., 887-936

Meissner, V. (2017), “The European Border and Coast Guard Agency Frontex beyond Borders - the Effect of the Agency's External Dimension" TARN Working Paper Series 16/2017 (available at https://ssrn.com/abstract=3085529)

Noël, E. (1963) 'Comment fonctionnent les institutions de la Communauté Économique Européenne', Revue du Marché Commun, Vol. 6, pp. 14-21

Olsen, J. (2003), “Towards a European Administrative Space?”, Journal of European Public Policy, Vol. 10, No. 4, pp. 506-531

Pag, S (1987), "The relations between the Commission and national bureaucracies", in Cassese (ed) The European Administration, Brussels: International Institute of Administrative Sciences, 443-496

Parejo Alfonso, L. (2000) Manual de Derecho Administrativo Comunitario (Centro de Estudios Ramón Areces)

Pedler, R.H. and Schaefer, G.F. (1996), Shaping European Law and Policy: The Role of Committees and of Comitology in the Political Process (Maastricht, EIPA)

Pizzolla, A. (2018) "The role of the European Central Bank in the Single Supervisory Mechanism: a new paradigm for EU governance", European Law Review 43(1), 3-23

Ritleng. D. (2017) (ed.), « La réforme du Frontex : du neuf vraiement ? Dans quelle mesure ?» Revue Trimestrielle de Droit Européen (3), pp. 437-524

Rivero, J. (1978), «Vers un Droit Commun Européen : Nouvelles Perspectives en Droit Administratif » in Cappelletti, M (ed.) New Perspectives for a Common Law of Europe, Bruxelles : Bruylant, 389-406

Ruffert, M. (2017), “The Constitutional Basis of EU Administratiev Law" in Rose-Ackerman, S.; Lindseth, PL.; Emerson, B. (eds) Comparative Administrative Law, Cheltenham: Elgar, 667679

Sand, IJ. (1998), "Understanding the New Forms of Governance: Mutually Interdependent, Reflexive, Destabilised and Competing Institutions" European Law Journal, Vol 4, No. 3, 271-293

Sandulli, A. (2015), "Il Ruolo della Scienza Giuridica nella Costruzione del Diritto Amministrativo Europeo", in Lucia, L. and Marchetti, B. (eds), L'Amministrazione Europea e le Sue Regole, Bologna: Mulino, 273-294

Saurer, J. (2017), "EU Agencies 2.0: The New Constitution of Supranational administration Beyond the EU Commission" in in Rose-Ackerman, S.; Lindseth, PL.; Emerson, B. (eds) Comparative Administrative Law, Cheltenham: Elgar, 619-631

Schmidt-Assmann, E. (1996), "Verwaltungskooperation und Verwaltungskooperationsrecht in der Europäischen Gemeinschaft", Europarecht, Vol. 31 No. 3, 270-301

Schütze, R. (2010) 'From Rome to Lisbon: 'Executive Federalism' in the (New) European Union”, Common Market Law Review, Vol. 47 No. 5, pp. 1385-1427 
Schütre, R. (2011) “Delegated” Legislation in the (New) European Union: A Constitutional Analysis', Modern Law Review Vol. 74, 674-689

Schwarze, J. (1992[2006]) European administrative law (London: Sweet \& Maxwell), $2^{\text {nd }} \mathrm{ed,}$

Simoncini, M. (2018) Administrative Regulation Beyond The Non-delegation Doctrine. A Study on EU Agencies (Oxford: Hart)

Shapiro, M. (1999), "The European Court of Justice" in Craig, P. and de Búrca (eds), The Evolution of EU Law, Oxford: Oxford University Press

Tauschinsky, E. and Weiß, W. (2018), The Legislative Choice Between Delegated and Implementing Acts in EU Law. Walking a Labyrinth (Cheltenham: Edward Elgar)

Trondal, J (2010), An Emergent European Executive Order, Oxford: Oxford University Press

Von Danwitz, T. (2008), Europäisches Verwaltungsrecht, Berlin: Springer

Wessels, W. (1998) 'Comitology: fusion in action. Politico-administrative trends in the EU system', Journal of European Public Policy 5(2): 209-34

Ziller J. (2014), 'Introduction: Les Concepts d'Administration Directe, d'Administration Indirect et de Co-administration et Les Fondements du Droit Administratif Européen » in Auby and Rochère (eds.), Traité de droit administratif européen (Bruylant, $2^{\text {nd }}$ ed.) pp. 327-334 